A survey is to be made soon of the Takamanda Forest in the Mamfe Overside which still contains a few families of the lowland gorilla, and a sanctuary will probably be created in the vicinity of Mbonye. In the recent revision of the Game Laws of West Cameroon both the gorilla and the chimpanzee were given full protection, such legislation being most desirable as a group of "animal collectors" in East Cameroon have already depleted several forest areas of their simian inhabitants.

Other developments are in progress and whereas a short time ago we were faced with a situation in which the wildlife of West Cameroon was being gradually exterminated, we now have two reserves providing havens of refuge for the wildlife, new game laws giving the fullest protection, and a Game Branch capable of enforcing them.

\title{
Rhino Reserve in Lake Victoria
}

This account of the transporting by the Tanzanian Game Department of black rhinoceros to Rubondo Island in Lake Victoria, which has been declared a Rhino Reserve, is based on work already reported by B. McCulloch, of the Veterinary Investigation Centre, and P. L. Achard, of the Game Division, in ORYX, August 1965, p. 131: "Mortality in the Capture of Game Animals".

TANZANIA has created a new reserve for black rhinoceros that is as near being 'completely safe' for these harassed animals as can be imagined. This is the 55,000-acre Rubondo Island in Lake Victoria, 20 miles long and 5 miles wide, which has been a Forest Reserve since the beginning of the century. No human settlement has been allowed on the island, and it has not been developed or exploited in any way. The Forest Division has agreed to it being used as a Rhino Reserve. With areas of open grassland, dense rain forest and open savanna, and an annual rainfall of 60 in. giving an abundance of shrubs and creepers, mostly palatable to rhino, it is ideal for the rhinos. There are no predators and the indigenous fauna includes vervet monkeys, situtunga, bushbuck, hippopotamus and otters.

The Game Department began catching operations in October 1963 in the Grumeti game controlled area to the east of Lake Victoria. Five animals were caught and taken to holding pens at Kirawira, where two cows became so tame that they could almost have been "driven to Rubondo by a good herdsman"; they could be induced to enter a crate "merely by calling their names and offering a titbit". Both were taken successfully to Rubondo in crates towed on a pontoon together with a third that was heavily in calf; ten days later this one was seen on the island accompanied by a calf.

In February 1964 a bull, taken direct from Mwanza on the southern shore of the lake, a journey of 90 miles, had a stormy passage. All went well for three hours; then a sudden electrical storm, for which Lake Victoria is notorious, tossed the rhino's crate on its pontoon so violently that the hawsers snapped, and for $2 \frac{1}{2}$ hours the rhino was 
tossed about until the tow ropes could be fixed, by which time the crate was only 200 yards from a rocky shore on which it would have been smashed to bits. By then the pontoon was shipping water. The crate was awash on arrival, but the rhino got to its feet, accepted some sugar cane, and was clearly none the worse for its battering.

In July and September seven more rhinos, captured in an area to the north across the Mara River where they were hemmed in by cultivation and being heavily poached, were taken to the island on one of the public ferries which the Public Works Regional Engineer agreed to release for the purpose; the journeys were made without hitch. By January 1965 eight mature cows and three bulls had been released on Rubondo. The transfers are being continued, and the East African Wild Life Society has generously agreed to help finance the removal of up to 40 animals.

On another island in Lake Victoria, Saanane, only half a mile off Mwanza, which is one of Tanzania's largest towns, a zoo has been established and gazetted as a game reserve. Most of the animals are allowed to range over the island, and visitors are restricted to a series of paths. The initiative for this Zoo was taken by Mr. J. S. Malecela, Tanzania's representative to the United Nations, when he was Regional Commissioner, with a view to introducing children to the wildlife of their country, for few settlements in Tanzania have electricity without which films cannot be brought to the people. An account of the Saanane Zoo will appear in the International Zoo Yearbook for 1965. A photograph is on Plate 11.

\section{In the Footsteps of the Elephants}

A $\mathbf{N}$ example of the interdependence of wildlife is described by A John Savidge, game warden in Tanzania, writing about the new Ruaha National Park, in a letter quoted from Animal Kingdom:

"The elephants here are bulldozers, ploughs, tree-fellers, water-borers, path-makers and dung-distributors. Without them the wilderness would look a different place indeed. And so many animals, birds, and insects are indirectly dependent on them for water supplies. We watched a herd scuffling out the sand of the dry watercourse near the camp here in the heat of the day. The sand was so hot that a mere human could not have endured to stand there, but the elephants spent a lazy three-quarters of an hour at their digging. They begin with the toes of the forefeet, where we would use the heel, then use the trunk when the hole gets deeper. Before the muscles of the trunk develop, the little calves drink water with the mouth direct, but not from these sandholes, which their clumsy efforts would fill in. They become bored with the proceedings and roll in the shade of the adults - the excavated sand is damp and cool. Immediately the elephants leave, a troop of baboons (which have been collecting on a fallen tree nearby, arms on knees and studied disinterest on every long face), drop down and rush across the white-hot sand to drink, heads and shoulders hidden in the ready-made holes. The same afternoon a group of five grey kudu cows cross the dry river bed and water there. Later there is the hum of honey-bees, amplified in the trunk-shaped tunnels. The dry surface sand grains cascade and fill the funnel-shaped hollows. Water stored below the sand keeps cooler and cleaner, and evaporgtes less than water exposed. Elephants prefer it to water taken from a running river." 